\title{
PANDUAN PENULISAN
}

\section{Indonesia Journal of Criminal law}

\section{Persyaratan Umum}

1. Panjang artikel antara 3000-5000 kata (termasuk kepustakaan, catatan-catatan, dan tabel)

2. Melampirkan pernyataan bahwa artikel belum pernah dipublikasikan sebelumnya, di mana pun dan dalam bentuk apapun.

3. Setiap artikel akan diuji keplagiatan/jiplak dimana $20 \%$ keatas artikel akan dikembalikan kepada penulis

4. Judul Komponen: Huruf Besar, Hitam, Pinggir Ke Kiri, Cetak Tebal, menggunakan huruf Calisto MT, ukuran 12

5. Sub-subkomponen tidak diberi pembaban (kecuali komponen hasil dan pembahasan), tetapi indikasi sub-sub komponen itu ada pada kalimat pertama dari suatu alinea dari komponen itu.

6. Artikel disajikan dengan komponen sebagai berikut:

Judul: Judul Artikel Maksimal 12 Kata Diketik Dengan Huruf Calisto MT, 14 Cetak Tebal.

Nama penulis: Nama penulis diketik di bawah judul dengan Huruf Calisto MT 101 cetak tebal, tanpa gelar dan tidak boleh disingkat. Di bawah nama ditulis bidang keahlian, nama institusi dan alamat email penulis.

Abstrak: menggunakan bahasa bahasa inggris dan Bahasa indonesia, huruf 11 Calisto MT, Miring. tidak boleh lebih dari $200 \mathrm{kata}$, satu alinea tanpa acuan (referensi) tanpa singkatan/akronim, dan tanpa footnote. Abstrak ditulis bukan dalam bentuk matematis, pertanyaan, dan dugaan. Abstrak berisi: tujuan penelitian, metode penelitian, hasil penelitian dan simpulan.

Kata Kunci: Gunakan kata-kata atau frasa yang spesifik menggambarkan isi artikel, kata kunci dipisahkan dengan titi koma (;), maksimal 5 kata

Coresponden author: menguraikan alamat lengkap penulis pertama beserta email lengkap, dicantumkan dibagian bawah sudut kanan artikel (sesuaikan template)

Pendahuluan: Pendahuluan diketik dengan huruf besar [Calisto MT 12 bold] berisi latar belakang diuraikan dengan state of the art penelitian sebelumnya minimal 5 literatur yang dikupas dapat menjastifikasi kebaharuan atau novelty penelitian, mengatasi suatu permasalahan, urgensi dan rasionalisasi kegiatan, tinjauan pustaka, rencana pemecahan masalah, dan pengembangan hipotesis, analisis GAP, solusi permasalahan, 
keterbaharuan ilmu, referensi sumber primer, uraikan tujuan dan hipotesis diakhir pendahuluan[font Calisto MT 11, normal]

Metode: Metode penelitian menjelaskan tentang: pendekatan, ruang lingkup atau objek, definisi operasional variable/deskripsi fokus penelitian, sampel/informan, bahan dan alat utama, teknik pengumpulan data, dan teknik analisis data [font Calisto MT 11, normal]

Hasil dan Pembahasan: Hasil penelitian disajikan dengan lengkap dan sesuai ruang lingkup penelitian menyajikan temuan/finding atau tren, memperbaiki hasil penelitian sebelum-sebelumnya. Hasil penelitian dilengkapi dengan tabel, grafik (gambar), dan/atau bagan. Tabel dan gambar diberi nomor dan judul. Hasil analisis data dimaknai dengan benar. Bagian pembahasan terpisah dari hasil, memaparkan hasil penemuan secara logis, mengaitkan dengan sumber rujukan yang relevan. Pembahasan mengandung: what/how: apakah data yang disajikan telah diolah (bukan tabel mentah) dituangkan dalam bentuk tabel atau gambar (pilih salah satu) serta beri komentar, (why) bagian pembahasan terlihat adanya kaitan antara hasil yang diperoleh dan konsep dasar dan/atau hipotesis, (What else) apakah ada kesesuaian atau pertentangan dengan hasil penelitian orang lain, uraikan pula implikasi hasil penelitian baik teoritis maupun penerapan. data [font Calisto MT 11, normal].

Simpulan dan Saran: Simpulan berisi rangkuman singkat atas hasil penelitian dan pembahasan. Simpulan adalah temuan penelitian yang berupa jawaban atas rumusan masalah peneitian atau tujuan penelitian dan hipotesis penelitian. Simpulan diuraikan singkat dan jelas. Bagian saran menguraikan aplikasi atau pengembangan ilmu, Simpulan dan saran tidak menggunakan point atau penomoran tetapi diuraikan dalam satu paragraf. [font Calisto MT 11, normal]

Acknowledgements/Ucapan Terima kasih: Uraikan siapa saja yang membantu langsung penelitian anda seperti penyandang dana (institusi yang disebut bukan personal), boleh dilengkapi dengan nomor kontrak penelitian.

Daftar Rujukan: Memuat sumber-sumber yang dirujuk dan minimal $80 \%$ berupa pustaka primer terbitan 5 tahun terakhir, pustaka primer seperti Jurnal nasional dan jurnal internasional, artikel hasil penelitian. Daftar rujukan ditulis sesuai dengan style American Psychological Association (APA) Fifth edition. Semua sumber yang tercantum dalam daftar pustaka harus ada dalam naskah artikel dengan menggunakan aplikasi referens seperti: mandeley, Zetero, AndNote dll. 
7. Artikel diketik dengan format Microsoft Office Word. Dengan menggunakan font Calisto MT ukuran 11, spasi tunggal di kertas A4. Format kertas 3-3-2-2 ( kiri-ataskanan-bawah).

8. Penulis dapat mengirimkan dan mendaftarkan artikel melalui online OJS Jurnal atau email ke ilininstitute@gmail.com 

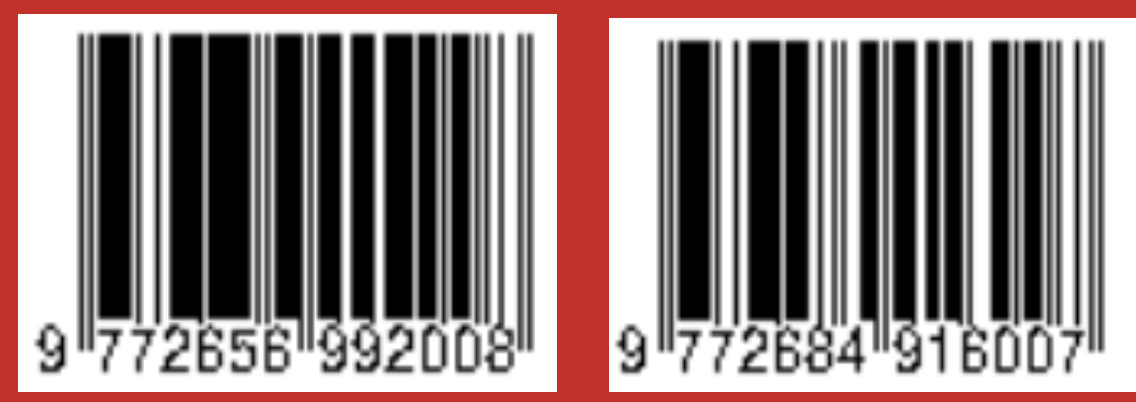